НАУКОВИЙ ВІСНин

sientific messenger of Lviv National University of

$\rightarrow$

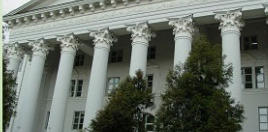

СЕРя "СльььКогосподАРСЬК НАУК

Том 22 № 93 2020
Науковий вісник Яьвівського національного університету ветеринарної медицини та біотехнодогій імені С.3. Гжицького. Серія: Сільськогосподарські науки

Scientific Messenger of Lviv National University of Veterinary Medicine and Biotechnologies. Series: Agricultural sciences https://nvlvet.com.ua/index.php/agriculture

UDC 636.4.082.43

\title{
Polygenic hereditary traits of young pigs and their association with the melanocortin receptor gene -4 (MC4R)
}

\author{
V. I. Khalak ${ }^{1}$, B. V. Gutyj ${ }^{2}$ \\ ${ }^{1}$ State Institution Institute of Grain Crops NAAS of Ukraine, Dnipro, Ukraine \\ ${ }^{2}$ Stepan Gzhytskyi National University of Veterinary Medicine and Biotechnologies Lviv, Ukraine
}

\section{Article info}

Received 26.08.2020 Received in revised form 28.09.2020

Accepted 29.09.2020

State Institution Institute of grain crops of NAAS, V. Vernadsky Str., 14, Dnipro, 49027, Ukraine.

Tel.: +38-067-892-44-04 E-mail:v16kh91@gmail.com

Stepan Gzhytskyi National University of Veterinary Medicine and Biotechnologies Lviv,

Pekarska Str., 50, Lviv,

79010, Ukraine
Khalak, V. I., \& Gutyj, B. V. (2020). Polygenic hereditary traits of young pigs and their association with the melanocortin receptor gene - 4 (mc4r). Scientific Messenger of Lviv National University of Veterinary Medicine and Biotechnologies. Series: Agricultural sciences, 22(93), 84-89. doi: $10.32718 /$ nvlvet-a9315

The article presents the results of studies of fattening and meat qualities of young pigs of different genealogical lines of large white breed and genotypes by the gene of melanocortin receptor - 4 (MC4R). The research was conducted in "Druzhba-Kaznacheyivka" LLC, the genetics laboratory of the Institute of Pig Breeding and APV NAAS and the animal husbandry laboratory of the State Institution Institute of Grain Crops NAAS. The work was performed according to the research program of NAAS №30 "Innovative technologies of breeding, industrial and organic production of pig products" ("Pig Breeding"). DNA-typing of the melanocortin-4 receptor gene (MC4R) was performed by Kim K., Larsen N., Short T. et al. (2000). Evaluation of young pigs for fattening and meat qualities was carried out taking into account the following quantitative characteristics: the average daily increase in live weight during the period of control fattening, $\mathrm{g}$; age of live weight $100 \mathrm{~kg}$, days; fat thickness at the level of 6-7 thoracic vertebrae, $\mathrm{mm}$; the length of the cooled carcass cm; the length of the bacon half of the cooled half-carcass, $\mathrm{cm}$. The length of the cooled carcass was measured with a measuring tape from the edge of the fusion of the pubic bones to the anterior surface of the first cervical vertebra; the length of the bacon half of the cooled half-carcass - from the anterior edge of the pubic bone to the middle of the anterior edge of the first rib (Berezovsky, Khatko, 2005). Conditions for feeding and keeping young pigs of the experimental groups were identical and complied with zootechnical standards. Economic efficiency of use of animals of various genotypes (MC4R $\left.{ }^{A A}, M C 4 R^{A G}\right)$ and biometric processing of the received data (Lakin, 1990). calculated according to generally accepted methods. It is established that young pigs of large white breed of controlled population at the age of reaching live weight of $100 \mathrm{~kg}$ exceed the minimum requirements of the elite class by 6.73, fat thickness at the level of 6-7 thoracic vertebrae - 30.84, length of chilled carcass $-3.52 \%$. Significant difference between animals of different genotypes by melanocortin 4 receptor gene $\left(M C 4 R^{A A}, M C 4 R^{A G}\right)$ was established by the average daily gain of live weight during the control period of fattening, the age of reaching live weight of $100 \mathrm{~kg}$, fat thickness at the level of 6-7 thoracic vertebrae, length half of the cooled half-carcass and a complex index of fattening and meat qualities (B. Tyler's index). Young pigs of large white breed line Kotilo UA 8819347 outperformed peers line Azuro UA 8800557 on average daily live weight gain during the control period of fattening by $5.29 \%$, the age of $100 \mathrm{~kg}$ live weight $-3.29 \%$, fat thickness at the level of $6-7$ breasts vertebrae $-7.14 \%$. The longer length of chilled carcass (by $1.13 \%$ ) and the length of bacon half of chilled half carcass (by $2.68 \%$ ) were characterized by animals of Azuro UA 8800557. The correlation coefficient between fattening and meat qualities in young pigs of large white breed of the controlled herd varies ranging from 0.865 ( $t r=22.26, P<0.001)$ to $+0.913(t r=35.43, P<0.001)$. The maximum increase in additional prod ucts was obtained from young pigs of the $M C 4 R^{A G}$ genotype $(+2.57 \%)$ and the genealogical line Kotilo UA $8819347(+4.86 \%)$, and its cost is $+694.26-1312.88$ UAH/head. in accordance.

Key words: young pigs, genealogical line, genotype, fattening and meat qualities, correlation coefficient, economic efficiency, variability. 


\title{
Полігенноспадкові ознаки молодняку свиней та їх асоціація 3 геном рецептора меланокортина - 4 (MC4R)
}

\author{
В. І. Халак ${ }^{1}$, Б. В. Гутий ${ }^{2}$ \\ 'Державна установа “Інститут зернових культур НААН України”, м. Дніпро, Україна \\ ${ }^{2}$ Львівський національний університет ветеринарної медицини та біотехнологій імені С. 3. Гюицького, м. Львів, \\ Україна
}

В статті наведено результати досліджень відгодівельних і м'ясних якостей молодняку свиней різних генеалогічних ліній великої білої породи та генотипів за геном рецептора меланокортину - 4 (MC4R). Дослідження проведено в СТОВ “ДружбаКазначеївка", лабораторії генетики Інституту свинарства і АПВ НААН та лабораторії тваринництва Державної установи “Інститут зернових культур НААН”. Роботу виконано згідно програми наукових досліджень НААН №30 "Інноваційні технології племінного, промислового та органічного виробнищтва продукції свинарства" (“Свинарство”). ДНК-типування за геном рецептору меланокортину - 4 (MC4R) проводили за Kim K., Larsen N., Short T. et al. (2000). Оцінку молодняку свиней за відгодівельними i м'ясними якостями проводили з урахуванням наступних кількісних ознак: середньодобовий приріст живої маси за період контрольної відгодівлі, г; вік досягнення живої маси 100 кг, діб; товщина шпику на рівні 6-7 грудних хребиів, мм; довжина охолодженої туші см; довжина беконної половини охолодженої півтуші, см. Довжину охолодженої туші вимірювали мірною стрічкою від краю зрощення лонних кісток до передньої поверхні першого шийного хребия; довжину беконної половинки охолодженої півтуші - від переднього краю лонної кістки до середини переднього краю першого ребра. Умови годівлі і утримання молодняку свиней піддослідних груп були ідентичними і відповідали зоотехнічним нормам. Економічну ефективність використання тварин різних генотипів $\left(M C 4 R^{A A}, M C 4 R^{A G}\right)$ та біометричну обробку одержаних даних розраховували за загальноприйнятими методиками. Встановлено, щзо молодняк свиней великої білої породи підконтрольної популяиії за віком досягнення живої маси 100 кг переважсає мінімальні вимоги класу еліта на 6,73, товщиною шиику на рівні 6-7 грудних хребиів - 30,84, довжиною охолодженої туші - 3,52 \%. Достовірну різниџю між тваринами різних генотипів за геном рецептору меланокортину 4 (MC4R $\left.{ }^{A A}, M C 4 R^{A G}\right)$ встановлено за середньодобовим приростом живої маси за період контрольної відгодівлі, віком досягнення живої маси 100 кг, товщиною шпику на рівні 67 грудних хребців, довжиною охолодженої туші, довжиною беконної половини охолодженої півтуші і комплексним індексом відгодівельних та м'ясних якостей (індекс Б.Тайлера). Молодняк свиней великої білої породи лінії Котіlo UA 8819347 переважсав ровесників лінії Azиго UA 8800557 за середньодобовим приростом живої маси за період контрольної відгодівлі на 5,29\%, віком досягнення живої маси 100 кг - 3,29\%, товщиною шиику на рівні 6-7 грудних хребиів - 7,14\%. Більшою довжиною охолодженої туші (на 1,13\%) та довжиною беконної половини охолодженої пів туші (на 2,68 \%) характеризувалися тварини лінії Azuro UA 8800557. Коефіцієнт кореляиії між відгодівельними і м'ясними якостями у молодняку свиней великої білої породи підконтрольного стада коливається у межсах -0,865 (tr = 22,26, $P<0,001)$ до +0,913 ( $\operatorname{tr}=35,43, P<0,001)$. Максимальну прибавку додаткової продукиї одержано від молодняку свиней генотипу $M C 4 R^{A G}(+2,57 \%)$ та генеалогічної лінії Kotilo UA 8819347 (+4,86\%), а ï̈ вартість становить $+694,26-1312,88$ грн./гол. відповідно.

Ключові слова: молодняк свиней, генеалогічна лінія, генотип, відгодівельні і м'ясні якості, коефіцієнт кореляції, економічна ефективність, мінливість.

\section{Вступ}

Важливими факторами збільшення виробництва високоякісної свинини, є покращення умов годівлі та утримання тварин різних виробничих груп, а також впровадження об'єктивних методів оцінки племінної цінності ремонтного молодняку, свиноматок та кнурівплідників основного стада. Так, за даними вітчизняних та зарубіжних вчених (Sheyko et al., 2005; Konoval et al., 2008; Balats'kyi et al., 2008; Loban \& Chernov, 2009; Maksimov \& Tupikin, 2009; Usatov et. al., 2009; Loban et al., 2011; Kapelański et al., 2013; Khalak et al., 2019; 2020) використання ДНК-маркерів та методу BLUP у селекційно-племінній роботі сприяє об'єктивній оцінці племінної цінності свиней різних порід, типів і ліній та відбору високопродуктивних тварин (Maksimov et al., 2015; Klimenko et al., 2016).

Мета роботи - дослідити відгодівельні і м'ясні якості молодняку свиней різних генеалогічних ліній великої білої породи та генотипів за геном рецептора меланокортину - 4 (MC4R) та розрахувати економічну ефективність результатів досліджень.

Для досягнення мети було визначено наступні завдання:

- провести відбір зразків біоматеріалу та ДНКтипування молодняку свиней великої білої породи;
- дослідити відгодівельні і м'ясні якості молодняку свиней різних генеалогічних ліній та генотипів за геном рецептора меланокортину - 4 (MC4R);

- розрахувати економічну ефективність результатів досліджень.

\section{Матеріал і методи досліджень}

Дослідження проведено в СТОВ “ДружбаКазначеївка", лабораторії генетики Інституту свинарства і АПВ НААН та лабораторії тваринництва Державної установи Інститут зернових культур НААН. Роботу виконано згідно програми наукових досліджень НААН № 30 "Інноваційні технології племінного, промислового та органічного виробництва продукції свинарства" (“Свинарство”).

Об’єктом досліджень був молодняк свиней великої білої породи різних генеалогічних ліній та генотипів за геном рецептора меланокортину - 4 (MC4R). Оцінку тварин за відгодівельними i м'ясними якостями проводили з урахуванням наступних кількісних ознак: середньодобовий приріст живої маси за період контрольної відгодівлі, г; вік досягнення живої маси 100 кг, діб; товщина шпику на рівні 6-7 грудних хребців, мм; довжина охолодженої туші см; довжина беконної половини охолодженої півтуші, см. Довжину 
охолодженої туші вимірювали мірною стрічкою від краю зрощення лонних кісток до передньої поверхні першого шийного хребця; довжина беконної половинки охолодженої півтуші - від переднього краю лонної кістки до середини переднього краю першого peбpa (Berezovskyy \& Khatko, 2005).

ДНК-типування за геном рецептору меланокортину - 4 (MC4R) проводили за (Kim et al., 2000; Korynnui et al., 2005).

Вік досягнення живої маси 100 кг розраховували за формулами:

якщуо жива маса тварини становила 85-99 ке:

$Д_{100}=\left[\left(100 \kappa 2-M_{0}\right) \div \frac{M_{0}-M_{n o}}{Д_{0}-Д_{n o}}\right]+Д_{0}$,

якщу жива маса тварини становила 101-115 ке:

$$
Д_{100}=Д_{0}-\left[\left(M_{0}-100 \kappa 2\right) \div \frac{M_{0}-M_{n o}}{Д_{0}-Д_{n o}}\right]+Д_{0},
$$

де: Д $100-$ вік досягнення живої маси 100 кг, діб; До - вік при останньому зважуванні, діб; Д по - вік попереднього зважування, діб; $\mathrm{M}_{0}$ - жива маса при останньому зважуванні, кг; $\mathrm{M}_{\text {по }}$ - жива маса при попередньому зважуванні, кг (Instruktsiya z bonituvannya svyney..., 2003).

Комплексний індекс відгодівельних і м'ясних якостей (індекс Б.Тайлера) (3) розраховували за формулою:

$$
I_{в}=100+(242 \times K)-(4,13 \times L) \text {, }
$$

де: Ів - комплексний індекс відгодівельних та м'ясних якостей (індекс Б. Тайлера), бала, К - середньодобовий приріст живої маси, кг; L - товщина шпи- ку на рівні 6-7 грудних хребців, мм; 242; 4,13 - постійні коефіцієнти (Vashchenko, 2019).

Умови годівлі і утримання молодняку свиней піддослідних груп були ідентичними і відповідали зоотехнічним нормам. Економічну ефективність використання тварин різних генотипів (MC4R ${ }^{\mathrm{AA}}, \mathrm{MC}^{\mathrm{AG}} \mathrm{R}^{\mathrm{AG}}$ ) (Metodika opredeleniya ekonomicheskoy effektivnosti ..., 1983) та біометричну обробку одержаних даних (Lakin, 1990) розраховували за загальноприйнятими методиками.

\section{Результати та їх обговорення}

Встановлено, що молодняк свиней підконтрольного стада $(\mathrm{n}=42)$ характеризується достатньо високими показниками відгодівельних і м'ясних якостей. Так, середньодобовий приріст живої маси тварин за період контрольної відгодівлі становить 774,6 \pm 5,82 г $(\mathrm{Cv}=4,69 \%)$, вік досягнення живої маси 100 кг $177,8 \pm 0,79$ діб $(\mathrm{Cv}=2,80 \%)$, товщина шпику на рівні 6-7 грудних хребців - 20,7 $\pm 0,34$ мм $(\mathrm{Cv}=10,79 \%)$, довжина охолодженої туші $96,5 \pm 0,36$ см $(\mathrm{Cv}=1,86 \%)$, довжина беконної половини охолодженої півтуші - 85,1 $\pm 0,50 \mathrm{~cm}$ $(\mathrm{Cv}=2,93 \%)$. Комплексний індекс відгодівельних і м'ясних якостей (індекс Б. Тайлера) коливається у межах від 178,90 до 232,84 балів.

Результати досліджень відгодівельних і м'ясних якостей молодняку свиней великої білої породи різних генотипів за геном рецептору меланокортину $4\left(\mathrm{MC}_{4} \mathrm{R}^{\mathrm{AA}}, \mathrm{MC} 4 \mathrm{R}^{\mathrm{AG}}\right)$ наведено в таблиці 1.

\section{Таблиця 1}

Відгодівельні і м’ясні якості молодняку свиней великої білої породи різних генотипів за геном рецептору

\begin{tabular}{|c|c|c|c|}
\hline \multirow{4}{*}{ Показники (ознаки), одиниці виміру } & \multirow{4}{*}{$\begin{array}{c}\text { Біометричні } \\
\text { показники }\end{array}$} & \multicolumn{2}{|c|}{ Генотип } \\
\hline & & $M C 4 R^{A A}$ & $M C 4 R^{A G}$ \\
\hline & & \multicolumn{2}{|c|}{ Група } \\
\hline & & I & II \\
\hline \multirow{4}{*}{$\begin{array}{l}\text { Середньодобовий приріст живої маси } \\
\text { за період контрольної відгодівлі, г }\end{array}$} & $\mathrm{n}$ & 22 & 20 \\
\hline & $X \pm S x$ & $756,8 \pm 5,61$ & $795,1 \pm 7,68 * * *$ \\
\hline & $\sigma \pm \mathrm{S} \sigma$ & $25,09 \pm 3,784$ & $36,04 \pm 5,702$ \\
\hline & $C v \pm S c_{v}, \%$ & $3,31 \pm 0,499$ & $4,53 \pm 0,716$ \\
\hline \multirow{3}{*}{ Вік досягнення живої маси 100 кг, діб } & $X \pm S x$ & $179,0 \pm 0,94$ & $174,4 \pm 1,11 * *$ \\
\hline & $\sigma \pm \mathrm{S} \sigma$ & $4,20 \pm 0,633$ & $5,20 \pm 0,822$ \\
\hline & $\mathrm{Cv} \pm \mathrm{Sc}_{\mathrm{v}}, \%$ & $2,34 \pm 0,346$ & $2,98 \pm 0,471$ \\
\hline \multirow{3}{*}{$\begin{array}{l}\text { Товщина шпику на рівні 6-7 грудних } \\
\text { хребців, мм }\end{array}$} & $X \pm S x$ & $21,4 \pm 0,55$ & $19,1 \pm 0,39 * *$ \\
\hline & $\sigma \pm \mathrm{S} \sigma$ & $2,47 \pm 0,372$ & $1,86 \pm 0,294$ \\
\hline & $\mathrm{Cv} \pm \mathrm{Sc}_{\mathrm{v}}, \%$ & $11,54 \pm 1,740$ & $9,73 \pm 1,539$ \\
\hline \multirow{4}{*}{$\begin{array}{l}\text { Комплексний індекс відгодівельних та } \\
\text { м’ясних якостей (індекс Б.Тайлера), } \\
\text { бала }\end{array}$} & $\lim$ & $178,90-209,41$ & $205,01-232,84$ \\
\hline & $X \pm S x$ & $191,48 \pm 1,923$ & $213,87 \pm 1,949 * * *$ \\
\hline & $\sigma \pm \mathrm{S} \sigma$ & $8,16 \pm 1,230$ & $8,26 \pm 1,306$ \\
\hline & $\mathrm{Cv} \pm \mathrm{Sc}_{\mathrm{v}}, \%$ & $4,26 \pm 0,642$ & $3,86 \pm 0,610$ \\
\hline \multirow{4}{*}{ Довжина охолодженої туші, см } & $\mathrm{n}$ & 9 & 15 \\
\hline & $X \pm S x$ & $95,1 \pm 0,35$ & $97,3 \pm 0,42 * * *$ \\
\hline & $\sigma \pm \mathrm{S} \sigma$ & $1,05 \pm 1,583$ & $1,63 \pm 0,257$ \\
\hline & $\mathrm{Cv} \pm \mathrm{Sc}_{\mathrm{v}}, \%$ & $1,11 \pm 0,167$ & $1,67 \pm 0,264$ \\
\hline \multirow{3}{*}{$\begin{array}{l}\text { Довжина беконної половини охоло- } \\
\text { дженої півтуші, см }\end{array}$} & $X \pm S x$ & $83,3 \pm 0,60$ & $86,2 \pm 0,57 * * *$ \\
\hline & $\sigma \pm \mathrm{S} \sigma$ & $1,80 \pm 0,271$ & $2,21 \pm 0,349$ \\
\hline & $\mathrm{Cv} \pm \mathrm{Sc}_{\mathrm{v}}, \%$ & $2,16 \pm 0,325$ & $2,56 \pm 0,405$ \\
\hline
\end{tabular}
меланокортину $4\left(\mathrm{MC}_{4} \mathrm{R}^{\mathrm{AA}}, \mathrm{MC} 4 \mathrm{R}^{\mathrm{AG}}\right)$

Примітка: $* *-\mathrm{P}<0,01, * * *-\mathrm{P}<0,001$ 
Дослідження показали, що молодняк свиней II групи переважає ровесників I за середньодобовим приростом живої маси за період контрольної відгодівлі на 38,3 г $(\mathrm{td}=4,02 ; \mathrm{P}<0,001)$, віком досягнення живої маси 100 кг - 4,6 діб ( $\mathrm{td}=3,17$; Р < 0,01), товщиною шпику на рівні 6-7 грудних хребців - 2,3 мм $(\mathrm{td}=3,43 ; \mathrm{P}<0,01)$, довжиною охолодженої туші $2,2 \mathrm{~cm}(\mathrm{td}=4,07 ; \mathrm{P}<0,001)$, довжиною беконної половини охолодженої півтуші - 2,9 см (td = 3,53; $\mathrm{P}<0,001)$.

За комплексним індексом відгодівельних і м'ясних якостей (індексом Б. Тайлера) різниця між тваринами II i I груп дорівнює 22,39 бала (td = 8,20; $>$ < 0,001).
Результати досліджень відгодівельних і м'ясних якостей молодняку свиней великої білої породи різних генеалогічних ліній наведено в таблиці 2.

Встановлено, що молодняк свиней великої білої породи лінії Kotilo UA 8819347 переважав ровесників лінії Azuro UA 8800557 за середньодобовим приростом живої маси за період контрольної відгодівлі на 43,1 г $(\mathrm{td}=2,59 ; \mathrm{P}<0,01)$, віком досягнення живої маси 100 кг - 5,7 діб (td = 4,10; $\mathrm{P}<0,001)$, товщиною шпику на рівні 6-7 грудних хребців - 1,5 мм $(\mathrm{td}=2,30 ; \mathrm{P}<0,05)$, комплексним індексом відгодівельних і м'ясних якостей (індексом Б. Тайлера) 18,13 бала $(\mathrm{td}=0,55 ; \mathrm{P}>0,05)$.

Таблиця 2

Відгодівельні і м’ясні якості молодняку свиней великої білої породи різних генеалогічних ліній

\begin{tabular}{|c|c|c|c|}
\hline \multirow{4}{*}{ Показники (ознаки), одиниці виміру } & \multirow{4}{*}{$\begin{array}{l}\text { Біометричні } \\
\text { показники }\end{array}$} & \multicolumn{2}{|c|}{ Генеалогічна лінія } \\
\hline & & Azuro UA 8800557 & Kotilo UA 8819347 \\
\hline & & \multicolumn{2}{|c|}{ Група } \\
\hline & & $\mathrm{I}$ & II \\
\hline \multirow{4}{*}{$\begin{array}{l}\text { Середньодобовий приріст живої маси } \\
\text { за період контрольної відгодівлі, г }\end{array}$} & $\mathrm{n}$ & 17 & 10 \\
\hline & $X \pm S x$ & $771,1 \pm 10,64$ & $814,2 \pm 12,76^{* *}$ \\
\hline & $\sigma \pm \mathrm{S} \sigma$ & $43,88 \pm 7,526$ & $47,69 \pm 10,668$ \\
\hline & $\mathrm{Cv} \pm \mathrm{Sc}_{\mathrm{v}}, \%$ & $5,69 \pm 0,975$ & $5,85 \pm 1,308$ \\
\hline \multirow{3}{*}{ Вік досягнення живої маси 100 кг, діб } & $X \pm S x$ & $173,2 \pm 1,16$ & $167,5 \pm 0,77 * * *$ \\
\hline & $\sigma \pm \mathrm{S} \sigma$ & $4,78 \pm 0,819$ & $2,34 \pm 0,523$ \\
\hline & $\mathrm{Cv} \pm \mathrm{Sc}_{\mathrm{v}}, \%$ & $2,75 \pm 0,471$ & $1,39 \pm 0,310$ \\
\hline \multirow{3}{*}{$\begin{array}{l}\text { Товщина шпику на рівні 6-7 грудних } \\
\text { хребців, мм }\end{array}$} & $X \pm S x$ & $21,0 \pm 0,43$ & $19,5 \pm 0,50^{*}$ \\
\hline & $\sigma \pm \mathrm{S} \sigma$ & $1,49 \pm 0,255$ & $0,70 \pm 0,156$ \\
\hline & $\mathrm{Cv} \pm \mathrm{Sc}_{\mathrm{v}}, \%$ & $7,09 \pm 1,216$ & $3,58 \pm 0,800$ \\
\hline \multirow{4}{*}{$\begin{array}{l}\text { Комплексний індекс відгодівельних та } \\
\text { м'ясних якостей (індекс Б. Тайлера), } \\
\text { бала }\end{array}$} & $\lim$ & $181,67-286,76$ & $205,01-305,84$ \\
\hline & $X \pm S x$ & $225,16 \pm 9,256$ & $243,29 \pm 31,533$ \\
\hline & $\sigma \pm \mathrm{S} \sigma$ & $38,16 \pm 6,545$ & $54,61 \pm 12,217$ \\
\hline & $\mathrm{Cv} \pm \mathrm{Sc}_{\mathrm{v}}, \%$ & $16,94 \pm 2,905$ & $44,64 \pm 9,986$ \\
\hline \multirow{4}{*}{ Довжина охолодженої туші, см } & $\mathrm{n}$ & 12 & 5 \\
\hline & $X \pm S x$ & $96,5 \pm 0,46$ & $95,4 \pm 0,50$ \\
\hline & $\sigma \pm \mathrm{S} \sigma$ & $1,62 \pm 0,331$ & $1,72 \pm 0,544$ \\
\hline & $\mathrm{Cv} \pm \mathrm{Sc}_{\mathrm{v}}, \%$ & $1,67 \pm 0,341$ & $1,80 \pm 0,569$ \\
\hline \multirow{3}{*}{$\begin{array}{lc}\text { Довжина } & \text { беконної } \\
\text { охолодженої півтуші, см }\end{array}$} & $X \pm S x$ & $85,8 \pm 0,99$ & $83,5 \pm 1,50$ \\
\hline & $\sigma \pm \mathrm{S} \sigma$ & $3,45 \pm 0,705$ & $3,53 \pm 1,117$ \\
\hline & $\mathrm{Cv} \pm \mathrm{Sc}_{\mathrm{v}}, \%$ & $4,02 \pm 0,882$ & $4,22 \pm 1,335$ \\
\hline
\end{tabular}

Примітка: * $-\mathrm{P}<0,05, * * *-\mathrm{P}<0,001$

Більшою довжиною охолодженої туші (на 1,1 см, $\mathrm{td}=1,64 ; \mathrm{P}>0,05)$ та довжиною беконної половини охолодженої півтуші (на 2,3 cм, td = 1,28; $\mathrm{P}>0,05$ ) характеризувалися тварини лінії Azuro UA 8800557.

Встановлено, що кореляційний зв'язок між відгодівельними і м'ясними якостями у молодняку свиней великої білої породи коливається у межах від -0,865 $(\operatorname{tr}=22,26, \mathrm{P}<0,001)$ до $+0,913(\operatorname{tr}=35,43, \mathrm{P}<0,001)$.

Достовірні зв'язки 3 імовірністю $\mathrm{P}<0,05-0,001$ встановлено за наступними парами ознак: середньодобовий приріст живої маси за період контрольної відгодівлі × вік досягнення живої маси 100 кг (-0,690, $\operatorname{tr}=8,53, \mathrm{P}<0,001)$, середньодобовий приріст живої маси за період контрольної відгодівлі $\times$ комплексний індекс відгодівельних та м'ясних якостей (індекс Б. Тайлера) $(+0,818, \operatorname{tr}=8,53, \mathrm{P}<0,001)$, вік досягнення живої маси 100 кг × комплексний індекс відгодівельних та м’ясних якостей (індекс Б. Тайлера) $(-0,615$, $\operatorname{tr}=6,40, \quad \mathrm{P}<0,001)$, довжина охолодженої туші $\times$ комплексний індекс відгодівельних та м'ясних якостей (індекс Б. Тайлера) $(+0,370, \operatorname{tr}=2,78, \mathrm{P}<0,01)$, середньодобовий приріст живої маси за період контрольної відгодівлі $\times$ товщина шпику на рівні 6-7 грудних хребців $(-0,440, \operatorname{tr}=3,54, \mathrm{P}<0,01)$, середньодобовий приріст живої маси за період контрольної відгодівлі $\times$ товщина шпику на рівні 6-7 грудних хребців $(-0,440, \operatorname{tr}=3,54, \mathrm{P}<0,01)$, середньодобовий приріст живої маси за період контрольної відгодівлі $\times$ довжина охолодженої туші $(+0,372, \operatorname{tr}=2,80, \mathrm{P}<0,01)$, вік досягнення живої маси 100 кг $\times$ товщина шпику на рівні 6-7 грудних хребців $(+0,435, \operatorname{tr}=3,48, \mathrm{P}<0,01)$.

Результати розрахунку економічної ефективності використання молодняку свиней великої білої породи різних генотипів за геном рецептору меланокортину 4 $\left(\mathrm{MC}_{4} \mathrm{R}^{\mathrm{AA}}, \mathrm{MC}^{\mathrm{A}} \mathrm{R}^{\mathrm{AG}}\right)$ та генеалогічних ліній наведено в таблиці 3. 
Таблиця 3

Економічна ефективність використання молодняку свиней великої білої породи різних генотипів за геном рецептору меланокортину $4\left(\mathrm{MC}^{2} \mathrm{R}^{\mathrm{AA}}, \mathrm{MC} 4 \mathrm{R}^{\mathrm{AG}}\right)$

\begin{tabular}{cccc}
\hline Генотип, генеалогічна лінія & $\begin{array}{c}\text { Середньодобовий при- } \\
\text { ріст живої маси за період } \\
\text { контрольної відгдівлі, г }\end{array}$ & $\begin{array}{c}\text { Прибавка додаткової } \\
\text { продукції, \% }\end{array}$ & $\begin{array}{c}\text { Вартість додаткової } \\
\text { продукції, грн./гол* }\end{array}$ \\
\hline Загальна вибірка & $774,6 \pm 5,82$ & - & $-2,29$ \\
MC4R & $756,8 \pm 5,61$ & $+2,57$ & $-618,62$ \\
MC4R & $795,1 \pm 7,68$ & $-0,45$ & $-121,56$ \\
Azuro UA 8800557 & $771,1 \pm 10,64$ & $+4,86$ & $+1312,88$ \\
Kotilo UA 8819347 & $814,2 \pm 12,76$ & \\
\hline
\end{tabular}

Примітка: * - ціна реалізації молодняку свиней на переробні підприємства регіону дорівнювала 46,5 грн/кг

Розрахунок економічної ефективності результатів досліджень показав, що максимальну прибавку додаткової продукції одержано від молодняку свиней генотипу MC4R ${ }^{\mathrm{AG}}(+2,57 \%)$ та генеалогічної лінії Kotilo UA 8819347 (+4,86\%), а їі вартість становить $+694,26$ - 1312,88 грн./гол. відповідно.

\section{Висновки}

1. Встановлено, що молодняк свиней великої білої породи підконтрольної популяції за віком досягнення живої маси 100 кг, товщиною шпику на рівні 67 грудних хребців і довжиною охолодженої туші переважає мінімальні вимоги класу еліта на 6,73, 30,84 і $3,52 \%$.

2. Достовірну різницю між тваринами різних генотипів за геном рецептору меланокортину 4 (MC4R ${ }^{\mathrm{AA}}$, $\mathrm{MC}_{4} \mathrm{R}^{\mathrm{AG}}$ ) встановлено за середньодобовим приростом живої маси за період контрольної відгодівлі, віком досягнення живої маси 100 кг, товщиною шпику на рівні 6-7 грудних хребців, довжиною охолодженої туші, довжиною беконної половини охолодженої півтуші і комплексним індексом відгодівельних та м’ясних якостей (індекс Б. Тайлера).

3. Молодняк свиней великої білої породи лінії Kotilo UA 8819347 переважав ровесників лінії Azuro UA 8800557 за середньодобовим приростом живої маси за період контрольної відгодівлі на 5,29 \%, віком досягнення живої маси 100 кг - 3,29 \%, товщиною шпику на рівні 6-7 грудних хребців - 7,14 \%. Більшою довжиною охолодженої туші (на 1,13 \%) та довжиною беконної половини охолодженої півтуші (на 2,68 \%) характеризувалися тварини лінії Azuro UA 8800557 .

4. Коефіцієнт кореляції між відгодівельними i м'ясними якостями у молодняку свиней великої білої породи підконтрольного стада коливається у межах від $-0,944(\operatorname{tr}=12,13, \mathrm{P}<0,001)$ до $+0,899(\operatorname{tr}=8,70$, $\mathrm{P}<0,001)$.

5. Максимальну прибавку додаткової продукції одержано від молодняку свиней генотипу MC4R ${ }^{\mathrm{AG}}$ $(+2,57 \%)$ та генеалогічної лінії Kotilo UA 8819347 (+4,86\%), а іiї вартість становить +694,26 - 1312,88 грн./гол. відповідно.

6. 3 метою прискорення селекційного процесу щодо покращення відгодівельних і м'ясних якостей молодняку свиней пропонуємо поряд 3 традиційними методами оцінки племінної цінності використовувати методи індексної та маркер-асоційованої селекції.

\section{References}

Balatskyi, V. M., Ovsyanyk, T. V., \& Korinnyi, S. M. (2008). Asotsiatsiyi heniv u populyatsiyi svyney velykoyi biloyi porody anhliyskoyi selektsiyi. Svynarstvo. Mizhvidomchyy tematychnyy naukovyy zbirnyk, 56, 41-45 (in Ukrainian).

Berezovskyy, M. D., \& Khatko, I. V. (2005). Metodyky otsinky knuriv i svynomatok za yakistyu potomstva $\mathrm{v}$ umovakh pleminnykh zavodiv i pleminnykh reproduktoriv. Suchasni metodyky doslidzhen' u svynarstvi. Poltava, 32-37 (in Ukrainian).

Instruktsiya $\mathrm{z}$ bonituvannya svyney; Instruktsiya $\mathrm{Z}$ vedennya pleminnoho obliku u svynarstvi (2003). Kyyiv: "Kyyivs'kyy universytet" (in Ukrainian).

Kapelański, W., Eckert, R., Jankowiak, H. et al. (2013). Polymorphism of ESR, FSH $\beta, R B P 4, P R L, O P N$ genes and their influence on morphometric traits of gilt reproductive tract before sexual maturity. Acta Vet. Brno, 82(4), 369-374. doi: 10.2754/avb201382040369.

Khalak, V. I., Cherniavskyi, S. E., Ylchenko, M. A., Petulko, P. V., \& Horchanok, A. V. (2019). Biokhimicheskiye pokazateli syvorotki krovi i ikh svyaz' s otkormochnymi i myasnymi kachestvami molodnyaka sviney raznykh genotipov po SNP c.1426 g>a gena retseptoru melanokortina 4 (Mc4r) Biotekhnologiya: dostizheniya i perspektivy razvitiya: sb. materialov IV Mezhdunar. nauchn.- prakt. konf. UO Polesskiy gosudarstvennyy universitet (g. Pinsk, 2022 noyabrya 2019 g.). Pinsk, 38-41. URL: https://www.elibrary.ru/item.asp?id $=41405800$ (in Russian).

Khalak, V. I., Gutyj, B. V., \& Stadnits'ka, O. I. (2019). Feeding and meat qualities of young pigs of different origin and intensity of formation in early ontogenesis. Scientific Messenger of Lviv National University of Veterinary Medicine and Biotechnologies. Series: Agricultural sciences, 21(91), 10-15. doi: 10.32718/nvlvet-a9102.

Khalak, V. I., Voloshchuk, V. M., Pocherniaiev, K. F., Smyslov, S. Yu., \& Ilchenko, M. O. (2020). Pokaznyky vidtvoryuvalnoyi zdatnosti ta yikh povtoryuvanist $\mathrm{u}$ svynomatok riznykh henotypiv $\mathrm{z}$ urakhuvannyam polimorfizmu G.1426G $>$ A hena MC4R Svynarstvo. Mizhvidomchyy tematychnyy naukovyy zbirnyk 
Instytutu svynarstva i APV NAAN, 74, 49-62. doi: 10.37143/0371-4365-2020-74-06 (in Ukrainian).

Khalak, V., Gutyj, B., Bordun, O., Ilchenko, M., \& Horchanok, A. (2020). Effect of blood serum enzymes on meat qualities of piglet productivity. Ukrainian Journal of Ecology, 10(1), 158-161. doi: $10.15421 / 202025$.

Khalak, V., Gutyj, B., Bordun, O., Horchanok, A., Ilchenko, M., Smyslov, S., Kuzmenko, O., \& Lytvyshchenko, L. (2020). Development and reproductive qualities of sows of different breeds: innovative and traditional methods of assessment. Ukrainian Journal of Ecology, 10(2), 356-360 doi: $10.15421 / 2020109$.

Khalak, V., Gutyj, B., Bordun, O., Horchanok, A., Ilchenko, M., Smyslov, S., Lytvyshchenko, L., \& Kuzmenko, L. (2020). Large White breed sows. Ukrainian Journal of Ecology, 10(4), 122-126. doi: $10.15421 / 2020178$.

Kim, K., Larsen, N., Short, T., Plastow, G., \& Rothschild, M. F. (2000). A missense variant of the porcine melanokortin 4 receptor (MC4R) gene is associated with fatness, growth, and feed intake traits. Mammalian Genome, 11(2), 131-135. doi: $10.1007 / \mathrm{s} 003350010025$.

Klimenko, A. I., Maksimov, A. G., Maksimov, G. V., \& Lenkova, N. V. (2016). Geny-markery produktivnosti svinomatok. Selektsiya s.-kh. zhivotnykh i tekhnologiya proizvodstva produktsii zhivotnovodstva: materialy Mezhdunar. nauchn.prakt. konf. (Donskoy GAU, 17 fevralya 2016 g.). Donskoy GAU, 181-189 (in Russian).

Konoval, O. M., Konoval, O. M., \& Bilek, K. (2008). Doslidzhennya polimorfizmu svyney velykoyi biloyi porody za henamy hospodars'ko-korysnykh oznak. Naukovi dopovidi NAU, 1(9), 1-15. URL: http://nd.nubip.edu.ua/2008-1/08komevt.pdf (in Ukrainian).

Korinnyy, S. M., Pochernyayev, K. F., \& Balats'kyy, V. M. (2005). Sherst' tvaryn yak zruchnyy ob'yekt vydilennya DNK dlya analizu za dopomohoyu PLR. Veterynarna biotekhnolohiya, 7, 80-83 (in Ukrainian).

Lakin, G. F. (1990). Biometriya. Moskva: Vysshaya shkola (in Russian).

Loban, N. A., \& Chernov, A. S. (2009). DNK-diagnostika priznakov produktivnosti sviney. Zhivotnovodstvo
Rossii. Spetsvyp. Svinovodstvo, 2(2), 23-24 (in Russian).

Loban, N. A., Vasilyuk, O. Ya., \& Sheyko, I. P. (2011). Povysheniye produktivnykh kachestv sviney belorusskoy krupnoy beloy porody $\mathrm{s}$ ispol'zovaniyem markernykh genov. Vestsí natsyyanal'nay akademíi navuk Belarusí, 3, 89-95. (in Russian).

Maksimov, G. V. (2016). Vliyaniye genov RYR1, ESR i N-FABR na myasnyye kachestva molodnyaka sviney. Glavnyy zootekhnik, 2, 26-32 (in Russian).

Maksimov, G. V., \& Tupikin, V. V. (2009). Vliyaniye polimorfizma gena ESR na dinamiku zhivoy massy podsvinkov krupnoy beloy porody. Agrarnyy vestnik Urala, 9(63), 95-95. URL: https://cyberleninka.ru/article/ n/vliyanie-polimorfizma-gena-esr-na-dinamiku-zhivoymassy-podsvinkov-krupnoy-beloy-porody/viewer (in Russian).

Maksimov, G. V., Maksimov, A. G., \& Lenkova, N. V. (2015). Genotip svinomatok po markernym genam i ikh produktivnost'. Aktual'nyye problemy proizvodstva svininy: materialy XXIV zasedaniya mezhvuzovskogo koordinatsionnogo soveta po svinovodstvu (pos. Persianovskiy, 22-23 oktyabrya $2015 \mathrm{~g}$ ). Donskoy GAU, 42-47 (in Russian).

Metodika opredeleniya ekonomicheskoy effektivnosti ispol'zovaniya $\mathrm{V}$ sel'skom khozyaystve rezul'tatov nauchno-issledovatel'skikh rabot, novoy tekhniki, izobreteniya, ratsionalizatorskikh predlozheniy. Moskva: VNIIPI (in Russian).

Sheyko, I. P., Loban, N. A., \& Vasilyuk, O. Ya. (2005). Razrabotka metodov molekulyarnoy gennoy diagnostiki i ikh ispol'zovaniye $\mathrm{v}$ svinovodstve Belorussii. Vestsí Natsyyanal'nay akademíi navuk Belarusí: Seryya agrarnykh navuk, 1, 62-66 (in Russian).

Usatov, A. V., Klimenko, A. I., Azarin, K. V. et al. (2014). The relationship between heterosis and genetic distances based on SSR markers in helianthus annuus. American Journal of Agricultural and Biological Science, 9(3), 270-276. doi: 10.3844/ajabssp.2014.270.276.

Vashchenko, P. A. (2019). Prohnozuvannya pleminnoyi tsinnosti svyney na osnovi liniynykh modeley selektsiynykh indeksiv ta DNK-markeriv: avtoref. dys.. na zdobuttya nauk. stupenya d-ra s.-h. nauk: spets. 06.02.01 "Rozvedennya ta selektsiya tvaryn". Mykolayiv, 1-43 (in Ukrainian). 